\title{
리우+20과 국제개발협력
}

장 재 현 ((사)글로벌발전연구원ReDI 선임연구원)

\section{목 차}

I. 서론

II. 리우 +20 의 배경과 회의 개요

III. '우리가 원하는 미래' 의 주요 내용

N. 결론

\section{I. 서론}

2012 유엔지속가능발전회의(United Nations Conference on Sustainable Development, 이하 UNCSD)' 가 지난 6월 브라질 제2의 도시 리우데자네이루에서 정부 대표 단을 비롯하여 유엔기구, 지방정부, 시민사회와 기업 등 약 5 만 여명이 참여하여 개최되었다. '리우회의' 라 알려진 역사적인 환경회의가 같은 장소에서 개최된 지 20 년 만에 다시 열렸기 때 문에 'Rio+20(리우+20)' 라는 별칭으로 더 잘 알려진 본 회의는 반기문 유엔사무총장의 말처럼 “지속가능발전에 관한 우리 시대의 가장 중요한 국제회의 중의 하나" 이다. 6월 20일에 개최된 리우+20 본회의 개막식은 이례적으로 “인류세(人類世)1)에 온 것을 환영합니다" 라는 제목의 3 분여의 다큐멘터리 동영상2)으로 시작되었다. 이 동영상은 우리가 살고 있는 시대를 1만 년 전

1) 인류세는 18세기 중반 산업혁명 이후 인간의 활동으로 기후와 생태계가 과거와 완전히 달라진 새 지질시대를 일컫 는 비공식적 용어로 노벨화학상 수상자 폴 크루첸(Paul Crutzen)이 대중화시킨 개념이다.

2) Welcome to the Anthropocene 동영상은 Globaia 홈페이지에서 확인 가능. (http://globaia.org/en/) 
에 시작된 충적세(冲積世)와 구분되는 새로운 지질시대인 인류세라 불러야 될 정도로 산업혁명 이후 인간의 활동으로 인하여 수천 년 인류의 역사뿐만 아니라 45억년 지구 역사에 전례가 없는 지구환경의 변화가 진행되고 있다는 것을 보여주었다. 본 동영상으로 개막식이 시작된 것은 유 한한 지구에서 무한한 성장을 추구하는 현재의 발전 방식을 시급히 전환하지 않으면 계속되고 있는 과학계의 경고대로 지구 생태계가 회복 불가능한 한계점(tipping point)을 넘어 서고 그 결과로 인류 생존과 발전의 기반 자체가 무너질 수 있다는 것을 강조하는 의미였다. 이러한 맥 락에서 리우 +20 은 하나뿐인 지구를 살리고 인류에게 지속가능한 삶과 미래를 보장하기 위해서 세계가 어떻게 공동으로 노력해나갈 것인지를 다시 한 번 결의하고 이를 위한 글로벌 지속가능 발전 거버넌스 체제의 구체적인 변화를 모색하는 자리였다.

리우+20은 ‘우리가 원하는 미래(The Future We Want)'라는 제목의 결과문서를 채택하면 서 회의 개최를 결의한 64 차 유엔총회부터 2 년여에 걸친 대장정을 마무리 하였다. 반기문 유엔 사무총장은 리우+20의 결과에 대해서 "다자주의의 중요한 승리이며 인류에게 새로운 방향을 제시”해주었다는 평가3)를 내렸다. 하지만 회의 전부터 미국과 유럽 발 경제 위기로 제도 구축과 재원 제공에 있어 중요한 위치를 차지하는 주요국 정상들의 불참이 예견되었고, 올해 초 공개된 협상문 초초안(Zero Draft)을 바탕으로 6월 전까지 진행된 예비협상 과정에서 대부분의 쟁점들 에 대한 합의 도출에 난항을 겪었던 결과대로, 반드시 다뤄졌어야 하는 긴급하고 중요한 결정사 항들이 최종 결과문서에서 아예 언급이 되지 않았거나 별도의 후속 절차를 만들어 '합의를 미루 기로 합의’ 함으로써 회의가 마무리 되었다. 이에 따라 회의 종료 후 “리우 플러스 20이 아니라 마이너스 20", "역사상 가장 긴 자살유서”, "1차 세계대전 이후로 가장 큰 집단적 리더십의 실 패”, “우리가 원하지 않는 미래”라는 평가가 쏟아져 나올 정도로 국제사회는 리우+20의 결과를 매우 미흡한 것으로 평가하고 있다. 반면에, 리우 +20 의 결과에 대해서 긍정적으로 평가하는 의 견들도 있다. 리우+20을 통해 국제사회의 지속가능발전에 대한 의지가 재확인 되었고, 정부와 국제기구뿐만 아니라 시민사회와 민간부문까지 포함하여 700여개의 자발적인 공약들이 만들어 졌으며, Post-2015를 대비하는 지속가능발전목표(MDGs) 개발에 합의하는 성과가 있었다는 것이다. 특히, 유엔기후변화협약 당사국총회 $(\mathrm{COP})$ 를 비롯한 최근의 다자간 국제회의들이 본회 의 기간을 연장하고서도 제대로 된 결과물조차 도출해내지 못했던 것과 비교해봤을 때 적어도 정해진 회의 기간 내에 공동의 합의문을 이끌어 낸 것은 주요한 성과로 봐야 한다는 것이다.

3) http://www.un.org/apps/news/story.asp?NewsID=42352\#.UH0A4W8m35U 
리우 +20 에서 다루어졌던 이슈들은 지속가능발전의 세 축인 경제적, 환경적, 사회적 지속가능 성과 관련된 대부분의 주제를 포함하기에 그 내용이 방대하고 복잡하다. 이에 본고4)에서는 리 우+20의 역사적 배경과 회의개요 및 주요 결과에 대해서 간략하게 알아보고, 주요결과 중 국제 개발협력의 관점에서 중요한 의미를 지니는 지속가능발전목표와 국내총생산(GDP)을 보완하는 지표의 개발에 대한 논의를 중심으로 그 의미와 전망에 대해서 알아보고자 한다.

\section{II. 리우+ 20 의 배경과 회의 개요}

\section{1. 회의배경}

리우+20을 이해하기 위해서는 UNCSD가 어떠한 역사적 배경을 가지고 탄생 하였고, 유엔 시스템 하에서 국제 지속가능발전 거버넌스가 어떻게 진보해 왔는지를 되짚어 보는 것이 중요 하다. 특히, UNCSD의 역사는 남북문제, 즉 북반구의 선진 산업국과 남반구의 개도국간의 치열 한 국제정치의 속성을 지니고 있기 때문에 양자가 이 문제를 역사적으로 어떻게 접근하고 풀어 왔는지를 이해하는 것이 리우+20에서 진행된 논의의 행간을 이해하는데 도움이 된다. 이러한 관점에서 지난 40 년간의 국제환경거버넌스의 역사를 간략히 살펴보고자 한다.

\section{1) 1972 년 스톡홀름 유엔인간환경회의}

리우 +20 의 역사적 배경은 40년 전으로 거슬러 올라간다. 1972년 환경문제를 중심 의제로 하 는 첫 번째 유엔회의인 유엔인간환경회의(UN Conference on Human Environment, $\mathrm{UNCHE}$ )가 전 세계 113 개국의 참여로 스웨덴 스톡홀름에서 개최 되었다. 이 회의의 결과로 스 톡홀름선언 및 행동계획이 채택이 되었을 뿐만 아니라 지구환경의 날(6월 5일)이 정해지고 유엔 환경계획(UN Environment Programme, UNEP)이 출범하게 되었다. 이 회의는 환경과 개발 의 문제를 놓고 남북 간의 입장 차이가 처음으로 확연하게 드러난 회의였다. 스톡홀름 선언문5) 을 보면 환경을 보호하는 것은 모든 국가의 의무라고 명시하면서도, 개도국의 환경문제는 '저개 발(under-development)' 에서 온다는 것을 분명히 하면서 환경에 대한 논의가 개도국의 개발

4) 본고의 내용은 저자가 작성한 장재현(2012)과 저자가 공동 저자로 작성한 남부원 · 이성훈 - 장재현(2012)의 내용을 바탕으로 작성되었음을 밝힙니다.

5) 스톡홀름선언 전문은 UNEP의 다음 링크 참조.

http://www.unep.org/Documents.Multilingual/default.asp?DocumentID=97\&ArticleID=1503\&l=en 
을 저해하는 요소로 작용하지 않도록 선진 산업국들이 개도국에 재정 및 기술 지원을 해야 한다 고 강조하고 있다. 이 시기의 개도국들은 선진국 주도로 국제환경문제에 대한 논의를 시작하는 것이 기존의 불평등한 경제적 관계나 기술적 의존도를 유지하여 자신들을 빈곤의 늪에 빠져버 리게 하려는 시도, 즉 전형적인 '사다리 걷어차기' 전략으로 인식을 하였다. 하지만 스톡홀름 회의를 통해 환경문제를 논의하는 국제회의 참여가 자신들의 경제발전에 도움이 되는 기술과 자본 원조로 연결될 수 있다는 생각을 가지게 되었다.

\section{2) 1987 브룬트란트 보고서}

1983 년 개최된 유엔총회는 환경과 개발의 문제를 조화롭게 해결하기 위해 장기적인 행동의제 를 만들어 갈 독립적인 세계환경개발위원회(WCED)를 설립하였고, 동 위원회는 그 결과물로서 의장이었던 전 노르웨이 총리의 이름을 딴 브룬트란트 보고서- "우리 공동의 미래(Our Common Future)"6)-를 1987년에 발간하였다. 이 보고서는 경제발전과 환경문제들 간의 관 계를 강조하면서, 빈곤퇴치가 지속가능발전을 위한 필수적인 조건임을 명확히 하였다. 또한, 이 보고서를 통해 지속가능발전의 개념이 "미래 세대가 그들의 필요를 충족시킬 능력을 저해하지 않으면서 현재 세대의 필요를 충족시키는 발전”이라고 정의되면서 국가 간의 형평성뿐만 아니 라 세대 간의 형평성이 국제환경거버넌스 논의의 중심 의제로 부상하였고, 지속가능발전을 위 한 세 가지 중심축(Pillar)으로 환경적, 경제적, 사회적 지속성이 제시되고 이들 간의 조화가 중 요하게 다루어지기 시작했다.

\section{3) 1992 유엔환경개발회의}

리우회의 또는 지구정상회의라고 널리 알려진 유엔환경개발회의(UN Conference on Environment and Development, UNCED)는 108명의 정상들을 포함한 178개국의 대표들 을 필두로 약 17,000 명이 참여한 20 세기 최대의 국제환경회의로서 1972 년 스톡홀름회의 20 주 년을 기념하여 1992년 6월 브라질 리우데자네이루에서 개최되었다. 이 회의의 결과로 리우선언 7)과 40장에 걸친 방대한 행동계획인 의제21(Agenda21)8)이 채택되었고, 이듬해부터 매년 5월 에 뉴욕에서 개최되는 유엔지속가능발전위원회(UN Commission on Sustainable

6) 브룬트란트 보고서 전문은 다음 링크 참조. http://www.un-documents.net/wced-oct.htm

7) 리우선언 전문은 다음 링크 참조.

http://www.unep.org/Documents.Multilingual/Default.asp?documentid=78\&articleid=1163

8) 의제21 전문은 다음 링크 참조. http://www.un.org/esa/dsd/agenda21/ 
Development, UNCSD)가 만들어졌을 뿐만 아니라, 일반적으로 세계 3대 환경협약이라고 불 리는 유엔기후변화협약(UNFCCC), 유엔생물다양성협약(UNCBD), 유엔사막화방지협약 (UNCCD)이 탄생하는 계기가 되었다. 스톡홀름 회의 이후 리우회의까지 20년 간 오존층 파괴 를 막기 위한 몬트리올 의정서의 성공적인 합의(1987)를 포함하여 국제 환경 거버넌스는 꾸준히 개선되어 왔다. 특히, 개도국들은 회의명의 변화에서도 알 수 있듯이 회의 참석을 통해 환경문 제뿐만이 아닌 자신들의 주관심사인 '개발' 문제가 동등하게 논의 되는 것을 지켜보면서 지속 가능발전에 대한 유엔 회의에 대해 상대적으로 더 우호적인 태도로 다가서게 되었다.

\section{4) 2002 지속가능발전세계정상회의}

리우회의의 10 주년을 기념하여 열린 지속가능발전세계정상회의(World Summit on Sustainable Development, WSSD)는 남아프리카공화국 요하네스버그에서 191 개국 21,000 명의 참여로 개최되었다. 이 회의의 주요 결과물은 요하네스버그 선언9)과 이행계획 (Johannesburg Plan of Implementation, JPOI)10)이다. 요하네스버그 선언은 지속가능발 전을 위한 10년간의 노력에도 불구하고 인류사회가 여전히 맞닥뜨리고 있는 도전들을 강조하 고, 지속가능발전에 대한 의지를 재확인하였다. 또한 다자간 파트너십의 중요성과 2000년 수립 된 유엔새천년개발목표(UN Millennium Development Goals, MDGs)를 비롯한 1992년 이 후 지속가능발전을 위해 전 세계적으로 결의되고 합의된 목표의 조속한 달성을 촉구하였다. 특 히 WSSD를 통하여 '모든 개발(경제적, 사회적, 환경적)은 지속 가능해야한다' 는 것이 개발의 주요한 원칙으로 합의가 되었다.

\section{2. 리우 +20 개요}

리우 +20 은 앞서 살펴본 역사적 맥락 하에서 리우회의 이후 20 년, 요하네스버그회의 이후 10 년간의 글로벌 지속가능발전 거버넌스의 성과와 한계를 평가하고 이를 바탕으로 갈수록 심각해 지는 복합위기- 식량, 에너지, 금융, 기후변화-에 인류 공동으로 현명하게 대처하기 위한 새로 운 방향제시를 모색하기 위해 개최되었다.

9) 요하네스버그 선언 전문은 다음 링크 참조.

http://www.un.org/esa/sustdev/documents/WSSD_POI_PD/English/POI_PD.htm

10) 요하네스버그 행동계획 전문은 다음 링크 참조.

http://www.un.org/esa/dustdev/documents/WSSD_POI_PD/English/POIToc.htm 
이번 리우 +20 의 목표는 1) 지속가능발전을 향한 새로운 정치적 약속을 확보하고, 2) 과거 지 속가능발전에 관한 주요 회의 합의사항의 이행수준을 평가하며, 3) 새롭게 떠오르는 문제들에 대응하는 것이다. 또한, 회의 주제는 크게 두 가지로 지속가능발전 및 빈곤퇴치 관점에서의 녹 색경제와 지속가능발전을 위한 제도적 체제이다. 다시 말해, “지속가능발전을 달성함과 동시에 여전히 개도국의 최우선 과제인 빈곤 문제를 해결하기 위한 녹색경제를 어떻게 추진해 나갈 것 인가” 에 대한 논의와 “지속가능발전을 달성하기 위한 현행 국제적 공조 및 조율 체제를 어떻게 개선할 것인가"에 대한 논의가 주를 이룬 회의였다.

Rio+20의 회의 구성은 좁게 보면 20일부터 22 일까지 총회장에서 개최된 각국 대표단 연설과 고위급 원탁회의를 의미하지만 실제로는 리우 +20 란 명칭 하에 여덟 개의 서로 다른 성격의 행 사들이 동시다발적으로 개최됐다. 먼저 Rio+20 공식 회의 단지인 RioCentro에서 열린 '공식 행사' 는 아래와 같다.

- 총회장에서의 고위급 원탁회의와 각국 대표들의 연설

- 유엔과 다양한 이해관계자가 진행한 '지속가능발전 학습센터' (SD-Learning)11)

- 브라질 정부 주도의 '지속가능발전 대화' (SD Dialogues)12)

- 회원국, 국제기구 및 주요그룹13)의 발표와 토론 중심의 부대행사(Side Event)14)

- 총회장 옆 국제기구와 주요 국가들의 홍보관(Pavilion)

그리고 다음 세 가지가 대표적인 '장외행사' 성격을 지닌 회의들이다.

11) 지속가능발전 학습센터의 자세한 내용과 결과는 다음 링크 참조.

http://www.uncsd2012.org/meetings_sdlearning.html

12) SD-Dialogues는 유엔과 브라질 정부는 산림, 물, 에너지 등 지속가능발전과 관련된 다양한 주제별로 명사와 전 문가들을 초청하여 시민사회를 위한 포럼을 제공하였다. 각 주제별로 최종적으로 결정된 제언들을 다음 링크 참 조. http://www.uncsd2012.org/sddialoguedays.html

13) 1992년 리우회의에서 채택된 의제21(Agenda 21)은 지속가능발전의 달성을 위한 근본적인 전제조건으로 의사결 정과정에서 폭 넓은 대중 참여(public participation)를 강조하고 이를 위해 아홉 개 주요그룹의 참여를 보장할 것 을 규정하고 있다. 아홉 개 주요그룹(Nine Major Groups)은 산업계, 어린이 및 청소년, 농부, 원주민, 지방정부, 비정부기구(NGOs), 과학기술계, 여성, 노동자 및 노동조합을 포함한다.

14) 다양한 부대행사의 자세한 내용은 다음 링크 참조. http://www.uncsd2012.org/meetings_sidevents.html

15) 민중 회의의 공식 홈페이지. http://cupuladospovos.org.br/en/

16) 기업지속가능성포럼의 공식 홈페이지. www.compact4rio.org

17) 2012 ICLEl 세계총회의 공식 홈페이지. http://worldcongress2012.iclei.org/

전 세계 911 개의 지자체가 참가한 이번 총회에 참석한 박원순 서울 시장은 세계 도시 리더들의 거버넌스 모임인 '기후변화세계시장협의회' (WMCCC: World Mayors Council on Climate Change)의 차기 의장으로 선출되었고. ICLEI 동아시아 본부의 서울 유치에도 성공했다. 
- 세계 각국의 $\mathrm{NGO}$, 농민, 여성, 원주민을 중심으로 리우의 플라멩고 해변에서 개최된 '생 명의 상품화에 반대하고 공공재를 지키는 사회적 환경적 정의를 위한 민중회의' (Peoples' Summit for Social and Environmental Justice in Defense of the Commons, against the Commodification of Life)15)

- 유엔글로벌콤팩트 주도로 리우 해변 호텔에서 열린 '기업지속가능성포럼' (Rio +20 Corporate Sustainability Forum)16)

- 리우 주변 벨로오리존치(Belo Horizonte) 시에서 개최된 지자체 중심의 '2012 ICLEI 세 계총회(2012 ICLEI World Congress)' ${ }^{17)}$

\section{III. ‘우리가 원하는 미래' 의 주요 내용}

Rio+20 본회의에서 합의한 정치적 선언문인 '우리가 원하는 미래' 는 아래에서 보는 바와 같 이 6장 283항으로 구성되어 있는 총 53 쪽 분량의 문서이다.

$$
\text { 〈우리가 원하는 미래〉 }
$$

I. 우리 공동의 비전

II. 정치적 약속 재확인
A. 리우 원칙 및 과거실행계획 재확인
B. 통합, 이행, 일관성의 증진
C. 주요그룹과 이해관계자들의 참여

III. 지속가능발전 및 빈곤퇴치 관점에서의 녹색경제

IV. 지속가능발전을 위한 제도적 체제
A. 지속가능발전의 세 가지 축 강화
B. 지속가능발전을 위한 정부 간 협의의 강화
- 유엔총회, 경제사회이사회, 고위급정치포럼
C. 지속가능발전의 환경 축
D. 국제금융기구들과 유엔의 활동
E. 지역적, 국가적, 국가 하위적, 지역적 차원

V. 행동 및 후속조치를 위한 체제
A. 주제별 분야 및 범분야 이슈:
$\mathrm{B}$. 지속가능발전목표

VI. 이행수단
A. 재원
B. 기술
C. 역량강화
D. 무역
E. 자발적 공약 등록부 
1 장에서는 미래를 위한 비전을 제시하고 있고, 2 장에서는 과거의 중요한 합의와 원칙들을 재 확인하고 있으며, 3 장과 4 장에서는 리우 +20 의 두 가지 주요 주제를 각각 다루고 있다. 그리고 5 장과 6 장은 회의에서 논의된 내용들을 실제적으로 우리의 삶에서 어떻게 이행할지에 대한 상 대적으로 실용적인 내용을 다루고 있다. 3 장에서는 결과문의 주요 내용 중 선진국과 개도국 간 의 논쟁이 치열했던 이슈들을 중심으로 최종 합의된 결과와 그 의미를 살펴보고자 한다.

\section{1) Rio+20 회의는 '개발/발전' 에 관한 회의}

1장 우리 공동의 비전(Our Common Vision)에서는 회원국들이 공동으로 추구하는 비전을 제시하고 있다. 특히, 2항에서는 빈곤퇴치를 “오늘날 인류가 당면한 가장 중요한 도전” 으로 규 정하며 빈곤의 해소가 지속가능발전의 필수불가결한 조건임을 강조하고 있다. 이는 UNCSD 회 의 자체가 1972년 ‘환경' 에 관한 회의로 시작되어 1992년 리우 회의와 2002년 요하네스버그 회의를 거치면서 '환경과 개발' 에 관한, 더 나아가 '지속가능발전' 에 관한 회의로 진화해 온 것 을 나타내주는 부분이다. 1972년 스톡홀름 회의에서 인도의 총리였던 인디라 간디가 "빈곤이야 말로 최악의 형태의 환경오염이다”라고 말했던 것처럼 선진국들이 세계 환경 문제의 극복을 개 도국과 함께 논의하고 대응하고자 한다면 개도국이 겪고 있는 빈곤의 문제를 바탕으로 논의를 시작해야 한다. 이러한 인식이 총 283항 중 두 번째에 반영되어 있는 것이다. 이러한 관점에서 국제개발협력의 주요 이슈들을 이해하고 향후 전망을 하고자 한다면 '개발/발전' 에 관한 가장 종합적이고 규모가 큰 국제회의인 Rio+20의 주요 협상 과정과 그 결과를 관심을 가지고 면밀 하게 살펴보아야 한다. 이번 합의문 내용의 특징 중 하나는 '지속되는 경제 성장(sustained economic growth)' 이라는 표현이 16번이나 등장한다는 것이다. 『작은 것이 아름답다(Small is Beautiful)」의 저자 E. F. 슈마허(Ernst Friedrich Schumacher)가 강조했듯이 "유한 세계 에서 물질 소비의 무한 성장은 불가능하다.” 따라서, 지속가능성(sustainability) 담론의 핵심 은 유한한 지구생태계에서 경제성장을 지속(sustained)하는 것이 아닌 주어진 한계 속에서 지 속가능한(sustainable) 삶의 방식을 찾아내는 것이어야 된다. 이러한 관점에서 경제성장의 지 속이 강조된 이번 결과문서는 지속가능성 측면에서 과거에 비해 오히려 퇴보한 느낌이다.

\section{2) '공통의 그러나 차별화된 책임 원칙' 의 재확인}

2장은 앞에서 말한 바와 같이 결과문서 전체에 적용되는 원칙을 재확인하는 중요한 장이기 때 문에 이번 Rio+20에서 선진국과 개도국들이 가장 치열하게 논쟁을 벌인 이슈가 15 항에 담겨있 다. 
15. 우리는 환경과 개발에 관한 리우 선언의 모든 원칙들, 그 중에서도 특히 리우 선언의 7번째 원칙 인 공통의 그러나 차별화된 책임 원칙을 재확인한다.

위에서 보듯이 15 항에서는 1992 년 리우 선언의 모든 원칙들을 재확인하면서 총 27 개의 원칙 들 중 유독 7번째 원칙인 '공통의 그러나 차별화된 책임(Common But Differentiated Responsibilities, 이하 CBDR) 원칙을 특별히 따로 빼내서 강조(single out)하고 있다. 리우 선언 원칙 7 의 전체 내용은 아래와 같다.

리우선언 (Rio Declaration) 원칙 7

각 국가는 지구생태계의 건강과 안전성을 보존, 보호 및 회복시키기 위하여 범세계적 파트너십의 정 신으로 협력하여야 한다. 지구의 환경악화에 대한 제각기 다른 책임을 고려하여, 각 국가는 공통의 그러나 차별화된 책임을 지닌다. 선진국들은 그들이 지구환경에 가하고 있는 압박과 그들이 소유하 고 있는 기술 및 재정적 자원을 고려하여 지속가능발전을 추구하기 위한 국제적 노력에 있어서 부담 하여야 할 책임을 인식하여야 한다.

지구환경문제를 해결하는데 있어서 전 세계 국가들이 공통의 책임을 지니고 함께 노력해야 하 지만 지구환경파괴에 미치는 역사적 · 현재적 책임을 고려했을 때 선진국들이 개도국에 비해 더 큰 책임을 떠맡아야 하며, 특히 선진국들이 소유하고 있는 친환경 기술을 개도국에 이전하고, 재정지원을 통해서 개도국의 지속가능발전에 기여해야 한다는 것이 상기 CBDR 원칙이 함의하 고 있는 바다. 이는 여전히 경제발전을 통한 빈곤퇴치가 일차적인 목표이며, 지구환경문제 악화 에 기여하는 바가 - 특히 국민 일인당 - 선진국에 비해 현격하게 적은 개도국 입장에서 당연하 다고 생각할 수밖에 없는 원칙이다. 따라서 개도국들은 1992 년 회의 이후 환경이 의제로 다루 어지는 모든 국제회의에서 $\mathrm{CBDR}$ 의 원칙을 지속적으로 특별히 강조해왔고 이번 Rio+20 회의 에서도 $\mathrm{CBDR}$ 에 대한 강조는 협상과정에서 가장 중요하게 다루어진 이슈 중의 하나였다.

반면 선진국은 CBDR 원칙 자체를 부정하는 것은 아니지만 1992년 리우선언이 채택된 후 이미 20년이라는 시간이 흘렀고, 개도국으로 분류되는 국가들 중 신흥산업국(중국, 인도, 브라 질 등)들이 급속도로 경제성장을 달성하고 있으며, 인구수와 경제규모를 감안했을 때 이제 개도 국들도 과거보다 더 큰 책임을 부담하지 않으면 지구 공통의 환경문제에 효과적으로 대응할 수 없다고 보고 있다. 중국이 미국을 제치고 전 세계 온실가스 최대배출국으로 떠오르는 것도 이러 한 선진국 인식의 전환에 기여를 했다. 따라서 $\mathrm{CBDR}$ 만을 결과문서 곳곳에서 특별히 따로 빼내 어 강조하는 것은 개도국들이 - 특히 신흥 산업국들이 - 이러한 증가된 책임조차 지지 않겠다 는 의미로 받아들여지기 때문에 선진국들은 이에 반대를 하는 것이다. 이는 협상과정에서 미국 
을 비롯한 유럽연합, 노르웨이, 일본, 스위스, 호주, 한국 등 대부분의 선진국의 입장이었으며 특히 미국의 토드 스턴 기후변화특사는 "CBDR이 온갖 군데에 다 들어 있는 것이 신경 쓰인다" 고 발언할 정도로 $\mathrm{CBDR}$ 만을 따로 빼내어 강조하는 것에 강하게 반대하였고 이것이 미국의 '마 지노선(red line)' 이라고 강조했다. 개도국을 대변하는 G77/중국 그룹은 $\mathrm{CBDR}$ 은 지속가능발 전을 위한 국제협력에 있어서 필수적인 원칙이며 $\mathrm{CBDR}$ 을 결과문서에 명확하게 언급하는 것이 역시 자신들의 마지노선이며 이는 협상이 불가함을 강조했다.

이렇게 합의점을 찾기 어려워 보이던 논쟁은 최종 문건에서 보는 것처럼 결국 $\mathrm{CBDR}$ 을 따로 빼내어 강조함으로써 개도국의 '판정승' 으로 끝이 난다. 한판승이 아니라 판정승인 이유는 개 도국 역시 결과문서 전체에서 두 곳 (리우 원칙을 언급하는 2 장 15 항, 유엔기후변화협약을 이야 기하는 5장 191항)에서만 $\mathrm{CBDR}$ 을 특별히 강조하고 나머지 부분에서는 $\mathrm{CBDR}$ 에 대한 언급을 삭제하는 방향으로 일정 부분 양보를 했기 때문이다. 또한 애초에 개도국들은 15 항에서 $\mathrm{CBDR}$ 의 원칙과 함께 형평성(equity)도 특별히 강조하고자 하였지만 최종문안에서는 선진국의 요구 대로 삭제되었다. 이처럼 상기 결과만 놓고 보면 크게는 개도국들에게 유리하게 협상이 마무리 된 것으로 보인다. 하지만, $\mathrm{CBDR}$ 원칙이라는 것이 이미 1992년에 합의가 된 부분인데 이를 따 로 빼내서 강조하느냐 마느냐의 문제에 많은 시간과 노력을 쏟음으로써 ' $\mathrm{CBDR}$ 원칙에 의거하 여 선진국이 개도국에 지고 있는 생태부채를 해결하기 위해 이미 과거에 약속했던 재정지원 및 기술지원을 제대로 이행하지 않은 부분을 어떻게 개선하고 앞으로 얼마의 새롭고 추가적인 재 정 부담을 질 것이냐 는 오히려 더 중요한 안건을 논의하는데 시간과 노력을 쏟지 못하는 결과 를 낳게 된 것을 볼 때 결국 $\mathrm{CBDR}$ 협상의 승자는 선진국으로 봐야 할 것이다. 특히나 지구환경 문제의 해결의 실패에 따른 피해는 선진국보다 개도국이 더 크게 입는다는 점을 생각하면 더욱 그렇다. 물론 글로벌 환경 거버넌스의 실패로 공동의 지구환경문제에 제때에 효과적으로 대응 하지 못해 받는 물적 - 인적 피해는 장기적으로 선진국, 개도국 구분 없이 인류 모두의 피해로 돌아오게 될 것이다. 따라서 길게 보면 결국 모두가 패자인 실패한 협상으로 평가 받게 될 것이 다.

\section{3) 녹색경제, 절반의 성공}

이번 Rio+20의 두 가지 주요 주제 중의 하나인 녹색경제는 결과문서의 3장에서 다뤄지고 있 다. 아래는 3 장의 첫 번째 항인 56 항의 내용이다.

동 문장을 면밀히 분석해보면 녹색경제가 지속가능발전을 달성하기 위한 중요한 수단 중의 하 나로 고려되고는 있지만 전체적인 문장의 표현에서 지난 9 호에서 언급한 바와 같이 개도국들이 
56. 우리의 중대 목표인 지속가능발전을 경제 · 사회 · 환경 세 가지 측면에서 모두 달성하는데 있어 서 각 국가가 처한 여건과 우선순위에 따라 적용 가능한 다양한 접근방식들과 비전과 모델과 도구들 이 있음을 확인한다. 이러한 관점에서 우리는 지속가능발전 및 빈곤퇴치 관점에서의 녹색경제를 지 속가능발전을 달성하기 위한 중요한 도구들 중의 하나로 간주하며 그것이 정책결정에 있어 옵션들을 제공해 줄 수는 있지만 엄격한 규정이 될 수 없음을 인식한다. 우리는 녹색경제가 지구생태계의 기 능을 건강하게 유지시키는 한에서 경제성장을 유지시켜줄 뿐만 아니라 빈곤을 퇴치하고 사회적 통합 을 증진시키며 인류의 복지를 개선하고 모두를 위한 고용의 기회와 좋은 일자리를 창출하는데 기여 해야만 한다는 점을 강조한다. [강조는 필자]

여전히 녹색경제에 상당한 의구심을 가지고 있음을 여실히 보여주며, 녹색경제라는 새로운 개 념이 회의의 두 가지 주요 주제 중 하나임에도 불구하고 그에 걸맞은 공감을 얻지 못하고 있는 것을 알 수 있다. 다시 말해, 56항이 녹색경제를 이야기하는 3장의 첫 번째 항임에도 불구하고 녹색경제에 대한 명확한 정의라든가, 녹색경제를 왜 추구해야 되는지, 녹색경제가 어떻게 지속 가능발전에 기여할 수 있는지에 대한 설명은 전혀 없이 녹색경제는 다양한 옵션 중의 하나일 뿐 임을 강조하며 녹색경제가 지켜야 될 내용들만 설명하고 있다. 더 나아가 58항에서는 개도국의 녹색경제에 대한 우려들이 무려 16 가지 조건의 형태로 자세히 나열되어 있다. 따라서 Rio+20 를 통해 새로운 글로벌 패러다임으로 부상하려던 녹색경제 담론은 여전히 매우 논쟁적인 위치 에 있다고 판단되며 제3세계와 지구시민사회는 녹색경제가 지구 생태계의 지속성 보다는 선진 국 경제성장의 지속성을 담보하기 위한 녹색분칠(green wash)에 지나지 않는다는 의심을 떨치 지 못하고 있는 것 같다. 그러므로 녹색경제를 지지하는 선진국들이 향후 녹색경제에 대한 전 지구적 합의를 강화하고 녹색경제로의 이행을 달성하고자 한다면 정부 간 뿐만 아니라 아홉 개 주요그룹들을 실질적으로 포괄하는 충분한 논의과정을 통해 녹색경제가 우리가 당면한 긴급한 지구환경문제의 해결에 있어서 과연 효과적이고 효율적인 해결책인지에 대해서 공감을 이끌어 낼 수 있어야 할 것이다.

\section{4) 고위급 정치 포럼의 신설}

또 하나의 Rio+20의 주요 주제였던 지속가능발전을 위한 제도적 체제(International framework for sustainable development: IFSD)에 대한 결정사항들은 4장에 담겨있다. 이 중 눈여겨봐야 할 부분은 84항에서 언급하고 있는 고위급정치포럼(High-level Political Forum)의 신설이다. Rio+20 회의 전에는 유엔 지속가능이사회(Sustainable Development Council)를 설립하자는 의견도 있었지만 결국 현재 유엔 경제사회이사회(ECOSOC) 내에 존재 
하는 지속가능발전위원회(Commission on Sustainable Development, 이하 CSD)를 장기적 으로 대체하는 것을 목적으로 지니는 고위급정치포럼이 만들어졌다. 앞으로 상기 포럼은 UN 체제 내 지속가능발전과 관련된 다양한 기구와 프로그램들에서 추구하는 정책들의 일관성과 조 화를 촉진하는 리더십을 발휘할 것으로 예상되지만, 지금까지 CSD가 해오던 역할과 어떤 차이 가 있을지는 2013년 68차 유엔총회 때 개최되기로 한 1차 포럼 때까지 지켜봐야 될 것이다

\section{5) 26 개의 우선순위 분야 선정}

5 장 A에서는 26 개의 지속가능발전의 우선순위 분야18)를 각각 다루고 있다. 이 중에서 이번 Rio+20에서는 에너지, 지속 가능한 교통, 해양과 바다 문제가 비중 있게 다루어 졌다. 또한, 2011년 개최되었던 제 19 차 CSD에서 선진국과 개도국의 첨예한 의견대립으로 이례적으로 CSD-19의 공식결과보고서까지 합의되지 못하게 만들었던 '지속 가능한 소비 및 생산에 관한 10 년 계획(10 YFP on SCP)'을 마침내 채택하게 된 것이 Rio+20의 주목할 만한 성과 중의 하 나로 꼽을 수 있겠다.

\section{6) 재정}

국제개발협력과 관련된 재정에 관한 부분은 결과문서 6장 이행수단 아래 A. Finance에서 다 루고 있다. 협상 과정에서 개도국들은 2013 17년 기간 동안 매년 300억불 이상, 2018년부터 는 매년 1,000 억불 상당의 재정지원과 '지속가능발전기금' 의 수립을 제안하였으나 선진국의 반대로 관련 논의의 진전은 없었다. 과거에 합의한 GNP 대비 $0.7 \% \mathrm{ODA}$ 지원 및 GNP 대비 $0.15 \sim 0.20 \%$ 최빈국 지원 목표를 재확인 하고 작년 부산총회( $\mathrm{HLF}-4)$ 를 비롯한 지난 몇 년간 의 국제개발협력 관련 회의에서 강조된 투명성, 책무성, 결과중심관리, 삼각협력, 기업의 역할 등을 강조하는 수준의 내용만 담겼다. 아쉬운 것은 5 월 22 일에 공개되었던 리우 +20 결과문서 공동의장 제안 초안(Co-Chairs Text)까지는 포함되어 있었던 '효과적인 개발협력을 위한 부 산 파트너십 이 최종 결과문서에서는 언급이 빠진 것이다. 특기할만한 것은 유엔총회 감독 하에 각 지역에서 임명한 총 30 명의 전문가로 구성된 정부간 위원회를 설립하여 2014년까지 지속가

18) 빈곤퇴치, 식량안보와 영양과 지속 가능한 농업, 물과 위생시설, 에너지, 지속 가능한 관광, 지속 가능한 교통, 지 속 가능한 도시와 거주지, 건강과 인구, 모든 이를 위한 전면적이고 생산적인 고용 및 좋은 일자리의 조장, 해양과 바다, 군소도서국, 최빈국, 내륙개발도상국, 아프리카, 지역적 노력, 재난 위험 감소, 기후변화, 산림, 생물다양성, 사막화와 토지황폐화 및 가뭄, 산, 화학물질과 폐기물, 지속 가능한 소비 및 생산, 채굴, 교육, 성평등과 여성의 권 한 강화 
능발전을 달성하기 위한 효과적인 재정전략이 담긴 보고서를 개발하도록 합의한 것이다 (255 257항).

\section{7) 지속가능발전목표(SDGs)의 설정}

기대했던 성과 없이 끝났다고 비판받는 Rio+20의 성과를 이야기 할 때 그나마 빠지지 않고 언급되는 것이 Post-MDGs 시대를 대비하는 지속가능발전목표(Sustainable Development Goals, SDGs) 개발에 합의했다는 것이다. SDGs에 대한 세부 내용은 5 장 아래 세부항목인 B 에 나와 있으며 총 7개 항(245-251)으로 구성되어 있다. 본고에서는 MDGs와의 관계, 원칙, 절 차, 분야, 성과 모니터링을 중심으로 $\mathrm{SDGS}$ 에 대한 협상결과를 보고자 한다.

\section{가. $\mathrm{SDGs}$ 와 $\mathrm{MDGs}$ 의 관계}

회원국들은 6월 초에 진행된 협상에서 우선적으로 $\mathrm{SDGs}$ 가 MDGs를 '대체' 하는 것이 아니 고 '보완' 하는 성격이 될 것임을 합의하였다. 개도국과 유럽연합은 모든 국가에 보편적으로 적 용될 SDGs로 인해 개도국만을 대상으로 하고 있는 MDGs의 달성이 방해 받는 것을 우려하였 다. 특히 SDGs의 설정으로 인해 선진국의 관심과 재정적 지원이 MDGs에서 SDGs로 옮겨 가 는 것을 매우 경계하였다. 이러한 맥락에서 SDGs의 첫 번째 항인 245항은 특정한 개발 목표를 달성하는데 있어서 MDGs와 같은 지표 설정 방식이 유용한 도구임을 강조하는 내용으로 시작 하여 MDGs를 목표한 바대로 약속된 기간 내에 달성하는 것에 대한 의지를 재차 확인하고 강조 하는 내용을 담고 있다.

\section{나. 원칙}

246 항에서는 SDGs가 준수해야 할 원칙과 규범들을 언급하면서 Post-2015 UN 개발 의제 들과 SDGs가 통합적으로 일관성 있게 추진되어야 한다는 것을 강조하고 있다. 특히 SDGs를 설정하는 것이 MDGs에 대한 관심을 떨어뜨리거나 노력을 줄이는 방향으로 진행되어서는 안 된다는 것을 재차 명시하고 있다. 협상과정을 보면 개도국들은 원칙을 언급하는 본 246항에서 도 $\mathrm{CBDR}$ 을 강조하고 싶었지만 앞에서 설명한 대로 결과문서의 두 곳에서만 특별히 언급하며 강조하기로 선진국과 합의하였기 때문에 본 항에서는 $\mathrm{EU}$ 가 중재안으로서 제안한 '국가별로 상 이한 여건, 능력, 우선순위를 고려하여 라는 표현이 $\mathrm{CBDR}$ 을 대체하고 있는 것을 볼 수 있다. 247 항에서는 SDGs가 행동 지향적이어야 하며, 간결하고, 소통에 용이하고, 수적으로 제한되 
고, 모든 국가에 적용 가능하되 각국의 현실, 역량, 발전수준 및 정책과 우선순위를 감안해야 함 을 강조하고 있다.

\section{다. 절차}

$\mathrm{SDGs}$ 를 설정하는 절차와 관련해서는 유엔총회 $(\mathrm{GA})$ 를 통한 정부 간 협상 중심의 절차를 따르 기로 합의하였다(248항). 협상과정에서 선진국들은 유엔사무총장 사무실 중심의 SDGs 설정 절 차를 제안하였는데 개도국이 유엔총회하의 정부 간 협상 중심의 절차를 강조하면서 최종적으로 변경이 된 것이다. 이에 따라 형평성 있고 균형 있게 유엔의 다섯 개 지역을 대표하는 30 개 국 가를 회원국이 임명하여 SDGs 개발을 위한 개방된 작업반(open working group)을 구성하기 로 하였다. 작업반은 착수단계에서 시민사회, 과학계 및 유엔시스템의 다양한 이해관계자와 전 문가들을 어떻게 참여시킬지를 포함하여 전반적인 SDGs 개발의 방법을 결정하고 종합적인 제 안서를 2013년 68회 유엔총회에 제출하기로 하였다. 따라서 국제개발협력에 관심이 있는 사람 들은 차후 작업반이 공개하는 SDGs 설정의 구체적인 절차와 방법에 대해서 관심을 가지고 면 밀하게 모니터링을 해야 할 필요가 있다.

\section{라. 분야}

$\mathrm{SDGS}$ 와 관련해서 사람들이 가장 관심을 가지는 것 중의 하나는 SDGs가 과연 어떤 분야를 포함할 것이냐 하는 문제다. 선진국들은 협상과정에서 대략적인 SDGs의 분야들을 결과문서에 포함시키고자 하였지만, 개도국은 결과문서에서 이미 지속가능발전의 중요 분야를 다루고 있음 을 강조하며 Rio+20에서 분야까지 정하는 것이 전체 협상을 방해할 수도 있다는 이유로 이를 반대했다. 247항에서 Rio+20에서 제시한 우선순위 분야에 집중해야 한다고 언급하고 있기 때 문에 차후 SDGs의 분야 논의에 있어서 5 장 $\mathrm{A}$ 에서 다루고 있는 26 개 분야가 기본이 될 것으로 예상된다.

\section{마. 성과 모니터링}

효과적인 목표의 달성을 위해서는 목표 (Goal) 자체도 중요하지만 구체적인 목표수준(target) 과 지표(indicator)를 어떻게 설정하느냐가 또한 중요하다. 목표수준과 지표를 무엇으로 정하느 냐의 문제는 분야를 선정하는 문제만큼이나, 혹은 그 이상으로 많은 논쟁을 불러일으키게 될 것 이다. 아직까지 SDGS와 관련해서 목표수준과 지표에 대한 구체적인 이야기가 논의된 적은 없 
지만, MDGs와 달리 발전 수준과 제반 여건이 매우 다양한 모든 국가를 대상으로 한다는 점에 서 같은 지표를 가지고 국가별로 목표 수준을 차별화하거나 지표 자체를 국가 여건에 따라 다르 게 적용하는 것이 가능할 것으로 예상된다.

\section{8) GDP를 보완하는 지표의 개발}

리우 +20 결과문서 2 장 38 항에서는 지속가능발전을 추구하는 과정에서 더 올바른 정책결정 을 위해서 현재 대표적인 발전의 지표로 사용되고 있는 국내총생산(Gross Domestic Product, $\mathrm{GDP})$ 을 보완하여 진보(progress)를 폭넓게 측정할 수 있는 지표의 개발에 대한 필요성을 언급 하고 있다. GDP를 보완할 수 있는 새로운 지표에 대한 필요성은 이미 오래 전부터 제기되어 왔 으며, 사르코지 전 프랑스 대통령의 요청 하에 노벨 경제학상 수상사인 아마르티아 센과 조지프 스티글리츠, 그리고 프랑스 경제학자 장-폴 피투시가 관련 연구를 진행하여 2010년에 발표19) 한 바 있다. OECD 역시 'Better Life Initiative'를 통해 단순한 경제지표인 GDP를 대체하는 지표를 연구했고 2011년 “당신의 삶은(How's Life)?” 이라는 보고서를 통해 그 내용을 공개20) 하였다. 삶의 질을 나타내주는 이러한 대안적인 지표는 이미 다양하게 개발되어 있다. 예전부 터 사용되던 UNDP의 인간개발지수(Human Development Index, HDI)나 부탄에서 모든 정 부 정책과 프로젝트의 심사에 실질적으로 적용되는 세계적으로 이미 유명한 '국민총행복지수 (Gross National Happiness, GNH)' 21)가 대표적이라고 할 수 있다.

앞으로 Rio+20의 합의대로 UN 통계위원회가 GDP를 보완하는 지표 개발을 위한 프로그램 을 시작한다고 하니 국내 국제개발협력계도 그 진행상황을 주의 깊게 모니터링 할 필요가 있다. 특히, OECD 국가 중 부동의 자살률 1위(2003 2009)와 출산율 꼴찌(2003 2009)를 기록하고 있을 뿐만 아니라, 영국 민간 싱크탱크 신경제재단(New Economy Foundation, NEF)에서 발 표한 2012 국가별행복지수(Happy Planet Index, HPI)22)에서도 전 세계 151 개 국 중 63위에 그친 우리 사회의 실정을 감안해보면 경제규모 15 위, 국민소득 2 만 불, 국가신용등급 상향등으 로 나타나지 않는 국민의 행복과 삶의 질을 평가하는 지표에 한국의 국제개발협력계도 더 많은

19) Stiglitz, J. E., Sen, A., \& Fitoussi, J.-P.(2010). Mismeasuring Our Lives: Why GDP Doesn't Add Up. The New Press.

20) OECD. (2011). How's Life?: Measuring Well-being. OECD Publishing. Retrieved from http://dx.doi.org/10.1787/9789264121164-en

21) $\mathrm{GNH}$ 관련 자세한 내용은 다음 링크 참조. http://www.grossnationalhappiness.com/

22) $2012 \mathrm{HPI}$ 인덱스는 다음 링크 참조. http://www.happyplanetindex.org/ 
관심을 가지고 연구를 할 필요가 있다. 영국의 대표적인 국제개발협력 싱크탱크인 ODI(Overseas Development Institute)는 2011년부터 개발과정에서 무엇이 효과가 있었는 지를 이해하고, 측정하고, 공유하는 4년짜리 연구 프로제트를 시행하고 있는데 이 중의 한 부분 이 진보를 측정하는 혁신적인 방법론을 연구하는 것이다. 이 프로젝트는 웹사이트 (www.developmentprogress.org)를 따로 개설하여 부탄의 GNH를 포함한 국가별 사례연구 도 제공하고 있어 국제개발협력에 관심 있는 사람들은 방문해 볼 가치가 있다.

현재 GDP 수준에 따라 결정된 OECD DAC의 수원국 리스트에 있는 국가들을 대상으로 우리 나라가 신흥 선진 공여국으로서 원조를 제공하고 있지만 $\mathrm{GDP}$ 가 아닌 삶의 질을 나타내주는 대 안적인 지표로 접근하면 우리의 원조를 받는 수원국이 우리보다 더 삶의 질이 높은 경우도 충분 히 있을 수 있다. 그렇다면, 우리가 급속한 경제발전의 과정에서 잃어버린 사회적으로 중요한 가치들을 여전히 지키고 있는 국가들에 원조 사업을 시행할 때 그들로 하여금 우리의 전철을 밟 지 않고 경제발전을 이룰 수 있도록 조언 할 수 있어야 한다. 또한 우리나라 역시 이러한 국가들 과의 원조 사업을 통해 우리가 잃어버린 가치들을 어떻게 다시 회복할 수 있을지를 고민해야 한 다. 이것이 가능해질 때 일방적인 '원조' 가 아니라 공여국들도 협력국들로부터 도움을 얻는 진 정한 국제개발 협력' 이 가능해 질 수 있으며 더 나아가 개발이 아니라 개발의 궁극적인 목적이 라고 할 수 있는 행복한 삶을 가능케 하는 '국제행복협력' 이 이루어질 수 있지 않을까 싶다. 일 인당 국민소득 2 만 2 천불인 한국인들이 과연 그 십 분의 일 수준인 $(\$ 2,288)$ 부탄인들 보다 행복 한가라는 물음에 우리 사회가 자신 있게 Yes라고 답할 수 없다면 한국의 정부 · 학계 · 시민사회 는 GDP를 보완하는 지표의 개발에 대한 Rio+20의 후속조치에 발맞춰 우리 내부적으로도 이에 대한 범사회적 논의를 시작하여 우리가 경제발전 과정에서 잃어버린 가치들이 무엇인지를 연구 하고 발전패러다임의 전환을 이루기 위한 사전 작업으로서 $\mathrm{GDP}$ 를 보완하면서 삶의 질을 나타 낼 수 있는 새로운 지표를 개발해야 할 필요가 있다.

\section{IV. 결론}

리우+ 20 로 연결되는 글로벌 지속가능발전 거버넌스의 시초라고 할 수 있는 스톡홀름 회의가 개최된 1972년에는 또 하나의 중요한 사건이 있었다. 바로 브레이크 없이 질주하던 선진국들의 경제성장 레이스에 제동을 건 로마클럽의『성장의 한계』보고서가 발간된 것이다. 이 보고서는 인구증가, 식량생산, 천연자원, 산업발전, 환경오염의 상호작용하는 경향이 변하지 않으면 결국 인류는 유한한 지구에서 성장의 한계에 부딪힐 것이라는 경고를 하였다. 40 년 전 성장의 한계 
에서 제시한 문제 인식의 프레임(Rome+40)을 가지고 리우+20을 바라보면 40년이란 시간이 무색할 만큼 근본적인 문제의 구조에 있어서는 큰 변화가 없는 것 같다. 오히려 그 당시에는 예 상하지 못하였던 더 복잡하고 심각한 지구환경문제의 위기 속에 우리는 여전히 효과적인 집단 적 해결책을 찾지 못하고 있다. 성장의 한계 보고서의 공동저자 중의 한 사람인 데니스 메도우 즈는 1972년 동 보고서가 처음으로 출간이 되었을 때 인류의 생태발자국은 지구의 수용능력의 $75 \%$ 정도였지만, 현재 인류는 이미 $150 \%$ 에 도달하였다고 발표했다. ${ }^{23)}$ 스톡홀름 회복력 센터 (Stockholm Resilience Center)는 2009년 연구를 통해 인류가 지속적으로 안전하게 살기 위 해서 넘지 말아야 하는 아홉 가지 안전한 행성 관리 범주(planetary boundaries)를 설정하였 는데, 발표 당시 이미 세 가지 범주(기후변화, 생물다양성, 생물권의 질소 유입)에서는 넘어선 것으로 결과가 나왔다. ${ }^{24)}$

이처럼 과학계의 지속적인 경고의 심각성에 비추어 볼 때 글로벌 지속가능발전 거버넌스의 진 보는 너무나 느리게 느껴진다. 20년 전에 이미 합의했던 내용들을 다시 한 번 확인하느라 재확 인(reaffirm)이라는 단어만 59번 등장하는 결과문서에 '우리가 원하는 미래'를 맡기기에는 너 무 부족한 것 같다. 유엔 다자주의 협상 방식의 구조적인 한계를 인식하고 중앙정부가 아닌 시 민사회의 다양한 이해관계자들이 혁신적인 방법을 통해 파트너십과 연대를 강화해나가는 방법 이외에는 해결책이 보이지 않는 것 같다. 이번 리우+20에도 본회의 보다 더 뜨거운 열기로 가 득한 곳은 시민사회의 다양한 단체들이 주도하는 부대행사가 벌어지는 회의장이었다. 또한 리 우+20을 보이콧한 수만 명의 농민, 여성, 원주민, $\mathrm{NGOs}$ 참가자들은 민중회의를 통해 별도의 논의와 정보 공유를 하면서 녹색경제가 보장해주지 않을 것으로 예상되는 가치들을 지키기 위 해 서로 긴밀히 연대하고 있었다.

실패라고 혹평 받는 리우+20이지만 지속가능발전목표를 개발하기로 합의한 것이나 GDP를 보완하는 지표의 개발에 합의한 것은 분명히 의미 있는 성과라고 할 수 있다. 특정 분야 및 개도 국을 대상으로 했던 MDGs에 비해 SDGs는 보편적으로 모든 국가에 적용될 수 있는 개발목표 로 설정될 것으로 예상된다. 앞으로 한국의 국제개발협력계도 Post-2015의 개발목표로 제시될 $\mathrm{SDGs}$ 의 개발과정에 대해 면밀히 모니터링 하면서 우리의 발전경험을 거울삼아 적절한 지속가 능발전목표의 분야, 절차, 모니터링 및 평가를 MDGs의 경험을 바탕으로 어떻게 다르게 개선해

23) leoforesta.com/2011/11/23/dennis-meadows-40-years-on/

24) http://www.nature.com/news/specials/planetaryboundaries/index.html 
나갈 것인지에 대한 논의와 연구를 할 필요가 있다. 또한, $\mathrm{GDP}$ 를 보완하는 지표의 개발을 유엔 차원에서 추진하기로 한 것은 매우 중요한 변화이니 후속조치를 모니터링 하면서, 경제 수준에 비해 삶의 질을 측정하는 지표에서 상대적으로 낮은 순위를 기록하고 있는 한국의 상황을 고려 하여 GDP로 측정되지 않는 가치들을 계량화하는 논의와 연구를 우리 사회도 관심을 가져야 할 것이다. 


\section{참고문헌}

\section{1. 국내문헌}

남부원, 이성훈, 장재현(2012). 국제개발협력의 관점에서 바라본 Rio+20의 결과와 전망. Issue Brief Vol. 10. KoFID \& KCOC \& ReDI.

리우 +20 한국민간위원회 (2012). 리우 +20 회의를 마무리하며 - 미완의 리우 합의 (http://eco.or.kr/?mid=report_data\&category=9427\&document_srl=77771)

이성훈 (2012). 리우+20에 대한 한국 시민사회의 평가. 리우+20 한국민간위원회 평가토론회.

장재현 (2012). 국제개발협력의 관점에서 바라본 Rio+20. Issue Brief Vol. 9. KoFID \& $\mathrm{KCOC} \& \mathrm{ReDI}$.

정지원, 박수경 (2012). Rio+20의 주요 결과와 정책적 시사점. KIEP.

환경부 (2012). Rio+20 성과와 향후 대응 방향. 리우+20한국민간위원회 평가토론회.

\section{2. 국외문헌}

Brooks, B. (2012) Rio+20, The Unhappy Environmental Summit. Associated Press. (http://bigstory.ap.org/article/rio20-unhappy-environmental-summit)

IISD (2012) Summary of the United Nations Conference on Sutainable Development: 13-22 June 2012.

Najam, A. (2005) Developing Countries and Global Environmental Governance: From Contestation to Participation to Engagement. International Environmental Agreements 5(3), 303 ?321.

OECD (2011). How's Life?: Measuring Well-being. OECD Publishing. Retrieved from http://dx.doi.org/10.1787/9789264121164-en

Stiglitz, J. E., Sen, A., \& Fitoussi, J.-P. (2010). Mismeasuring Our Lives: Why GDP Doesn't Add Up. The New Press.

TWN (2012). TWN RIO+20 News Update No. 1 23. Third World Network. (http://twnside.org.sg/title2/rio+20/rio+20_news_updates.htm)

UN (2012) The Future We Want. A/CONF.216/L.1 